\title{
ІНФОРМАЦІЙНА СИСТЕМА ДЛЯ ОТРИМАННЯ ТА ОБРОБЛЕННЯ МІКРОСКОПІЧНИХ ЗОБРАЖЕНЬ ЦИРКУЛЮЮЧИХ ПУХЛИННИХ КЛІТИН
}

\author{
๑С. М. Злепко1, Т. А. Чернишова ${ }^{3}$, С. В. Тимчик', В. Є. Кривоносов², О. С. Злепко \\ Вінницький національний технічний університет ${ }^{1}$ \\ Приазовський державний технічний університет \\ Медичний центр авіаційного університету, Київ \\ Вінницький національний медичний університет імені М. І. Пирогова ${ }^{4}$
}

\begin{abstract}
PЕзЮМЕ. У статті наведено структуру та реалізацію інформаційної системи для отримання та оброблення мікроскопічних зображень ЦПК. Визначено, що ідентифікація ЦПК є складною задачею, яка практично недоступна клінічним лікарям через відсутність відповідних медичних протоколів і технологічних стандартів їх виявлення. Наведено методи виділення ЦПК, а саме: технології поділу за морфологічними ознаками, метод поділу за градієнтом щільності, з використанням центрифугування і подальшого виділення технологією OncoQuick ЦПК, імуномагнітні методи, в яких пухлинні клітини взаємодіють з антитілами проти маркерів ЦПК з кон'югованими магнітними частинками, після чого ракові клітини можна отримати за допомогою магнітного поля, та їх недоліки. Розроблено інформаційну систему для отримання та аналізу мікроскопічних зображень ЦПК, яка складається з 4 підсистем: фільтрації венозної крові; отримання і попередньої обробки зображень ЦПК; формування зображень ЦПК та «інтелектуальної» обробки зображень ЦПК, яка, разом з підсистемою фільтрації венозної крові пацієнта, представляє собою базовий структурний елемент інформаційної технології для визначення циркулюючих пухлинних клітин в крові людини. Особливістю розробленої системи є введення до її структури підсистеми «інтелектуальної» обробки зображень ЦПК, яка виконує функції підсистеми підтримання прийняття рішень і забезпечує практично 100 \% відповідність встановленого діагнозу реальній ситуації, виключивши неоднозначність в його інтерпретації. Знайдено вирішення проблеми, а саме застосування запропонованої авторами інформаційної системи для отримання та оброблення мікроскопічних зображень ЦПК для ранньої діагностики онкологічних захворювань.
\end{abstract}

КЛючОВІ СЛОВА: циркулюючі пухлинні клітини; виявлення пухлинних клітин; комп'ютерний аналіз.

Вступ. Виявлення ЦПК при різних локалізаціях злоякісних новоутворень в теперішній час одне із актуальних питань онкології. Відмінною особливістю ЦПК $є$ агресивний потенціал, набутий в результаті еволюції клона, що дозволяє розглядати їх як основний механізм пухлинної прогресії. Вивчення біологічних характеристик ЦПК, на відміну від більшості інших злоякісних клітин, представлених в первинній пухлині, говорить про появу принципово нових онкомаркерів, з високим прогностичним значенням [1].

В даний час значні зусилля зосереджені на оптимізації технічних аспектів виділення і оцінки ЦПК з периферійної крові хворих на рак передміхурової залози (РПЗ) і в основному направлені на зменшення якісних та кількісних помилок при підрахунку ЦПК, а також мінімізацію втрати ЦПК, викликаної надмірним забором крові під час обробки. Більшість доступних підходів для захоплення ЦПК засновані на їх відмінностях від нормальних клітинних компонентів крові за фізичними (розмір, щільність, різниця потенціалів) і молекулярними (наприклад, поверхнева експресія) характеристиками.

На сьогодні ЦПК у крові хворих на ранній рак (NO) молочної залози виявляється в 30 \% випадків, у хворих на місцеворозповсюджений $(\mathrm{N}+)$ рак - в $36 \%$, у хворих на рак з метастазами - в $70 \%$ випадків [1].

Технологія автоматичної цифрової мікроскопії (ADM) дозволяє оптичним методом оцінювати кількість ЦПК у зразку. Процес займає досить багато часу при скануванні великих за площею цитологічних препаратів, тому технологію вдосконалили і розробили масивне оптоволоконне сканування (FAST). Новий підхід дозволяє за той же час просканувати в 500 разів більшу площу, порівняно з технологією ADM, без втрати чутливості. Спільне використання FAST і ADM допомагає виявити рідкісні епітеліальні клітини з усього зразка крові після попередньої обробки флуоресцентно-міченими антитілами до цитокератинів $[2,3]$. Інший метод виявлення циркулюючих епітеліальних ракових клітин з необробленої крові під назвою MAINTRAC полягає в використанні скануючої лазерної цитометрії зразків крові, які пройшли процедуру фарбування антитілами проти клітин, що експресують епітеліальні молекули клітинної адгезії (ЕРСАМ), проти лейкоцитів (CD45-аллофікоціан) [4].

Багато дослідників при визначенні ЦПК у крові хворих на рак молочної залози використовували систему CellSearch компанії Veridex [5]. Ця технологія отримала схвалення Управління з контролю за продуктами харчування та медичними 
Огляди літератури, оригінальні дослідження, погляд на проблему виробами США (Food and Drug Administration, FDA, USA) для виявлення рівнів ЦПК у пацієнтів з метастазами. Система $\epsilon$ напівавтоматичною, в іï основі лежать методи імунофлуоресценції, імуномагнітного поділу і проточної цитометрії [6]. Однак для клінічного використання вона досі не отримала дозволу. Система відокремлює лейкоцити від ракових епітеліальних клітин, а потім підраховує останні. Межа чутливості даного приладу склала 5 і більше ЦПК на 7,5 мл крові [5, 7-10]. Подібний CellSearch принцип роботи реалізований і в системі під назвою Ariol [11].

Досить нова і перспективна технологія СТСchiр, яка заснована на використанні мікропроточної системи, дозволяє кількісно визначати наявність ЦПК в крові за допомогою зв' язування клітин з антитілами ЕрСАМ, якими вкритий чіп. Чутливість методу висока (99 \%), а технологія дозволяє проводити аналіз досить малих обсягів крові (2-3 мл) [13].

Методи виділення ЦПК можна поділити на дві категорії. До першої належать технології поділу за морфологічними ознаками $[12,14,15]$. Чутливість даного методу дозволяє виділити більше 1 епітеліальної клітини на один мілілітр крові. На сьогодні технологія удосконалюється в сторону отримання недеформованих клітин, оскільки часто в процесі виділення клітини деформуються і руйнуються $[12,14]$. Метод поділу за градієнтом щільності з використанням центрифугування (Ficoll-Hypaque GE Healthcare) і подальшого виділення технологією OncoQuick ЦПК, не має достатньої чистоти, тому розробка даного методу триває $[15-17]$.

В іншу категорію виділення ЦПК входять імуномагнітні методи, в яких пухлинні клітини взаємодіють 3 антитілами проти маркерів ЦПК 3 кон'югованими магнітними частинками, після чого ракові клітини можна отримати за допомогою магнітного поля. На одному з таких методів грунтується робота систем MACS, RosseteSep, OncoQuick [1820]. Однак слід зазначити, що фірма AdnaGen розробила більш досконалу систему, в якій ЦПК піддають дії антитіл з магнітними мітками проти і епітеліальних, і пухлинно-специфічних маркерів [21]. AdnaGen виробляє набори для діагностики раку молочної залози, простати, кишечника.

Численні технології були використані для виділення та аналізу ЦПК у пацієнтів з РПЗ. Незважаючи на хороші результати, кожен з використаних підходів має свої обмеження, що виражаються в основному в складності виділення всієї субпопуляції пухлинних клітин через їх фізичну та біологічну різнорідність. Оцінка результатів при РПЗ в залежності від обсягу виділених ЦПК поступово стає доступною для лікарів. Проте процедура виділення ЦПК до сих пір не прийнята більшістю клініцистів. ЦПК мають значний потенціал в якості надійного неінвазивного джерела пухлинних клітин та як альтернатива біопсії. Дослідження ЦПК дає не тільки розуміння механізмів молекулярних і клітинних змін при РПЗ у конкретного пацієнта, але дозволяє в режимі реального часу проводити моніторинг лікування і прогнозувати можливе прогресування захворювання. В кінцевому рахунку ЦПК знайдуть своє місце в клінічній практиці і тим самим послужать збільшенню виживаності онкохворих.

Інформаційна система для отримання та аналізу мікроскопічних зображень ЦПК складається з 4 підсистем: фільтрації венозної крові; отримання і попередньої обробки зображень ЦПК; формування зображень ЦПК та «інтелектуальної» о6робки зображень ЦПК, яка, разом з підсистемою фільтрації венозної крові пацієнта, представляє собою базовий структурний елемент інформаційної технології для визначення циркулюючих пухлинних клітин у крові людини. Особливістю розробленої системи $\epsilon$ введення до ії структури підсистеми «інтелектуальної» обробки зображень ЦПК, яка виконує функції підсистеми підтримання прийняття рішень і забезпечує практично $100 \%$ відповідність встановленого діагнозу реальній ситуації, виключивши неоднозначність в його інтерпретації. Це досягається застосуванням блоків моделювання зображень, визначення параметрів ЦПК, встановлення діагнозу (прийняття рішень) i блоку формалізації експертних знань, в якому формується початкова структура предметної області, моделі ЦПК, та алгоритми функціонування Б3. Блок формалізації виконує також процедури ранжування та узгодження експертних знань, орієнтованих на досягнення адекватного рішення. Ще однією особливістю підсистеми «інтелектуальної» обробки зображень $\epsilon$ наявність структурованої бази даних, яка функціонує під управлінням СУБД MySQL і включає в себе бази даних еталонних зображень, еталонних параметрів ЦПК, діагнозів, критеріїв оцінки діагнозу та інші.

Структурна схема IC представлена на рисунку 1. Отримання зображення фільтрованої венозної крові після підсистеми ії фільтрації здійснюється за допомогою електронного мікроскопа - тринокуляра, оснащеного автоматичним управлінням механікою предметного стола та оптичної системи. Вихідне мікроскопічне зображення подається на світлочутливу матрицю або сенсор, яка $\epsilon$ головною частиною оптичного блоку і формує фотографічне зображення досліджуваного зразка. Матриця представляє собою масив світлочутливих комірок, кожна з яких виробляє електронний сигнал, пропорційний інтенсивності світлового потоку, що падає на неї. 


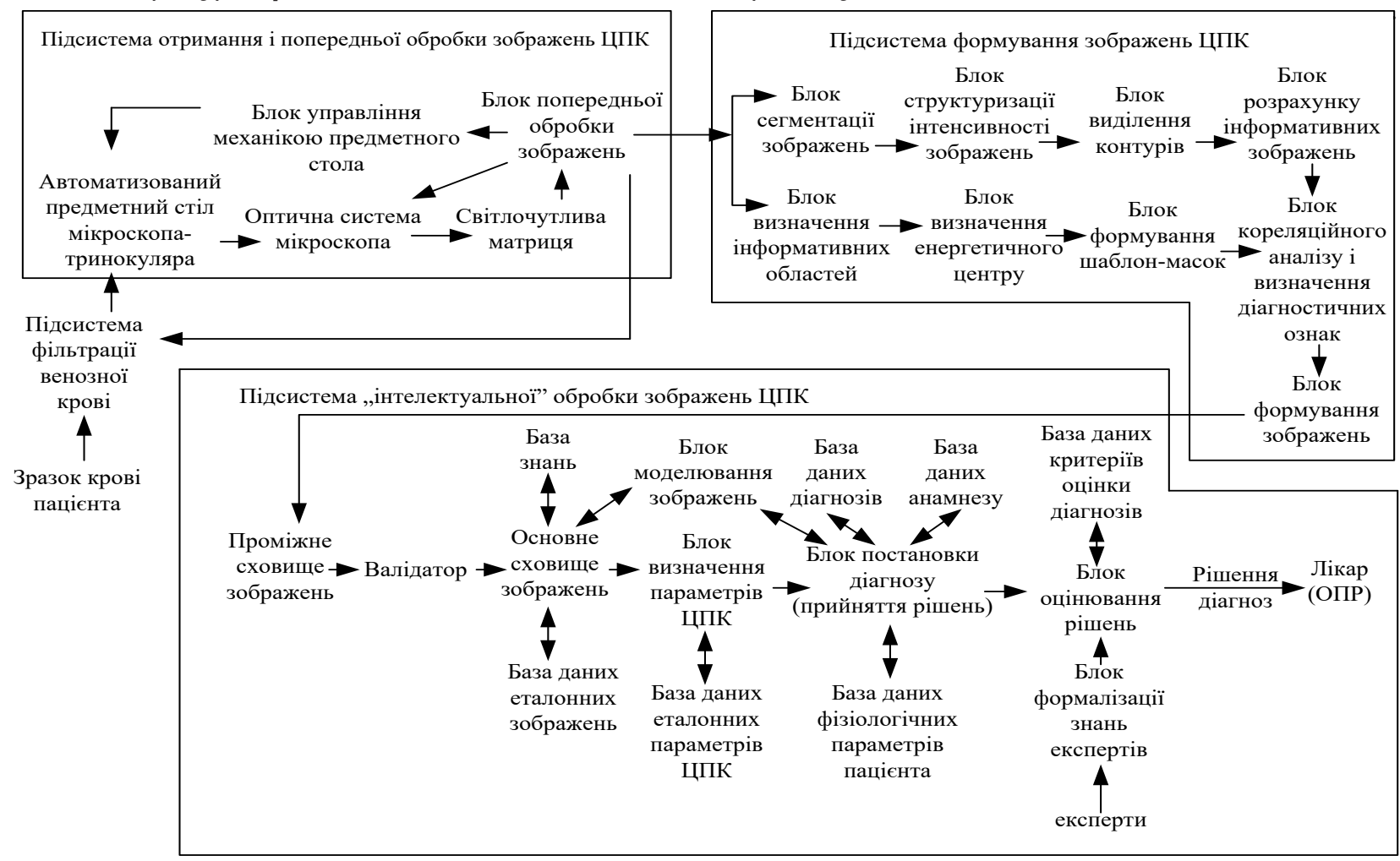

Рис. 1. Структурна схема інформаційної системи для отримання та аналізу мікроскопічних зображень ЦпК.

У більшості сенсорів кожна комірка «покрита» червоним, синім або зеленим фільтром. Фільтри зібрані в групи по чотири, причому на два зелених припадає по одному червоному і одному синьому (такий тип організації фільтрів називається «шаблоном Байєра»). Це зроблено так тому, що людське око найбільш чутливе до зелених кольорів. Кожний фільтр пропускає на світлочутливу комірку переважно свою складову світла. Тепер кожна комірка містить інформацію не тільки про яскравість, але і про колір окремого елемента зображення. Залишається тільки перетворити електричний сигнал у цифровий, обробити його і зберегти на карті пам' яті або мікродрайві.

Сенсори розрізняють за способом знімання інформації зі світлочутливої матриці $[16,19]$.

В CCD-сенсорах інформація зчитується послідовно з кожної комірки, рядок за рядком. Фоточутливий, розміром з поштову марку, кристал напівпровідника, названий приладом із зарядовим зв'язком (ПЗ3), слугує для перетворення світлового потоку в електричний сигнал. ПЗЗ містять сотні тисяч або навіть мільйони резисторів чи елементів вибірки. Чим більше елементів-комірок у ПЗ3, тим вищі роздільна здатність і якість зображення. При відкриванні затвора фотокамери світло, потрапляючи на комірки ПЗ3, приводить до утворення електричного заряду. У темних місцях заряд відсутній. Для одержання кольо- рового зображення воно пропускається через багатошаровий набір, що містить червоний, синій і зелений світлофільтри. Після цього світло потрапляє на пікселі ПЗ3, які чутливі до червоного, синього або зеленого кольору. Ця комбінація пікселів і утворить повнокольорове зображення. CCD-матриці простіші і більш економічні у виро6ництві, а прийнятий ними сигнал менш «зашумлений», що полегшує його обробку [16-18].

CMOS-матриці влаштовані інакше: для кожної комірки задано координати в матриці $(X, Y)$, i, використовуючи їх, можна одержати індивідуальний доступ до окремої комірки. Замість ПЗЗ використовуються КМОН-давачі (комплементарні структури метал-оксид-напівпровідник), які виконують функцію реєстрації потрапляння променя світла на кожний з сотень тисяч елементів вибірки. У кристалах КМОН можна реалізувати безліч інших функцій, таких як аналого-цифрове перетворення, обробка завантаженого сигналу, керування балансом білого та ін. Вони значно дешевші і простіші у виготовленні, споживають менше енергії $[18,19]$.

Блок формування зображення здійснює послідовне сканування елементів світлочутливої матриці, в результаті чого формується кадр зображення, який передається далі. Крім інформаційних сигналів, що несуть інформацію про яскравість та колір елементів зображення, блок фор- 
Огляди літератури, оригінальні дослідження, погляд на проблему

мування зображення формує сигнали піксельної синхронізації CLK, горизонтальної синхронізації HSYNC та вертикальної або кадрової синхронізації VSYNC, які необхідні для однозначного подання зображення у цифровому вигляді $[16,19]$.

USB-інтерфейс з'єднує між собою хост і пристрої. Хост знаходиться всередині персонального комп' ютера і управляє роботою всього інтерфейсу. Для того, щоб до одного порту USB можна було підключати більше одного пристрою, застосовуються хаби (пристрої, що забезпечують підключення до інтерфейсу інших пристроїв). В USBінтерфейсі використовується спеціальний термін «функція» - логічно закінчений пристрій, який виконує яку-небудь специфічну функцію. Топологія USB-інтерфейсу складається з 7 рівнів [16].

Всі передачі даних у вигляді пакетів по інтерфейсу ініціюються хостом. B USB-інтерфейсі використовується кілька різновидів пакетів:

- пакет-ознака (token paket) описує тип і напрямок передачі даних, адресу пристрою і порядковий номер кінцевої точки. Пакети-ознаки бувають декількох типів: IN, OUT, SOF, SETUP;

- пакет з даними (data packet), який містить передані дані;

- пакет узгодження (handshake packet), призначений для повідомлення про результати пересилання даних. Пакети узгодження бувають декількох типів: ACK, NAK, STALL [16].

B USB-інтерфейсі використовуються такі типи передачі інформації [16].

1. Керуюча передача (control transfer) - використовується для конфігурації пристрою і містить не менше двох стадій: Setup-стадія і статусна стадія, між якими може розташовуватися стадія передачі даних.

2. Потокова передача (bulk transfer) - використовується для передачі великого обсягу інформації і характеризується гарантованою безпомилковою передачею даних між хостом і функцією.

3. Передача з перериванням (interrupt transfer) - використовується для передачі невеликого обсягу інформації, для якого важливо його своєчасне пересилання. Має обмежену тривалість і підвищений пріоритет відносно інших типів передач і може містити IN- або OUT-пересилання.

4. Ізохронна передача (isochronous transfer), або потокова передача даних у реальному часі. Ізохронні транзакції містять фазу передачі ознаки і фазу передачі даних, але не мають фази узгодження [20].

Включення до структури IC підсистеми підтримки прийняття рішень зумовлено існуючою невизначеністю при встановленні основного діагнозу і прийняття рішень щодо тактики лікування. В той же час, експертна частина ПППР повинна функціонувати навіть в умовах повної невизначеності. Завжди існує можливість зміни бази знань системи, що буде сприяти її нормальному функціонуванню, а кінцевий результат буде залежати від частоти проявів деяких характеристик, при умові, що не було введено порогове значення [21].

Представити модель даних з неповною інформацією можемо таким чином. Компонент вектора користувача, який створюється в результаті виконання програми, приймає значення 1, якщо ознака точно присутня; 0 - відсутня та $X$, якщо у користувача $\epsilon$ сумніви. Якщо $\epsilon X$, це значить, що комірка вектора заповнена 0 або 1. Кількість векторів, в такому випадку, зросте до 2n, де n- число позицій, що мають невизначені значення:

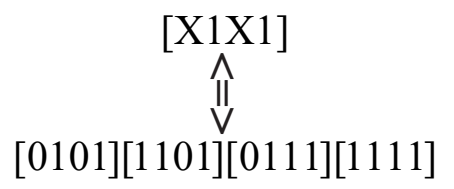

В умовах невизначеності при встановленні діагнозу слід вводити різні правила, що враховують особливості конкретного захворювання. Це можуть бути і вагові коефіцієнти ознак, і рангові пріоритети, які надаються кожній ознаці за допомогою функції власності, що представляє собою суб'єктивну міру, під якою, за визначенням, слід розуміти релевантність елемента поняттю, яке визначається відповідною нечіткою сукупністю [21].

Формування структури і змісту бази знань в розробленій ПППР було виконано поетапно (рис. 2) за участі експертів та автоматизованого особистісного анамнезу. Для побудови логічних медичних діагностичних правил на основі алгоритмів отримання даних із значень динамічних показників стану пацієнта, необхідно обрати лише ті зміни параметрів, які можна вважати статистично достовірними [22].

Достовірність визначалась за відомими формулами і критеріями Стьюдента, стандартного відхилення, стандартної помилки середнього, ймовірності похибки та іншими.

Для підвищення точності і достовірності о6робки даних та зменшення помилок до виходу проміжного сховища зображень підключено валідатор, який і виконує вищезазначені функції.

Іще одним елементом системи забезпечення достовірності, адекватності діагнозу та оцінки кількості ЦПК на досліджуваному зображенні $\epsilon$ блок оцінювання рішення (діагнозу). Процедура оцінювання має два рівні контролю: суб' єктивний (експерти) та об'єктивний (критерії). Остаточне рішення (діагноз) приймається тільки при умові збігу оцінок експертів і критеріальної. 


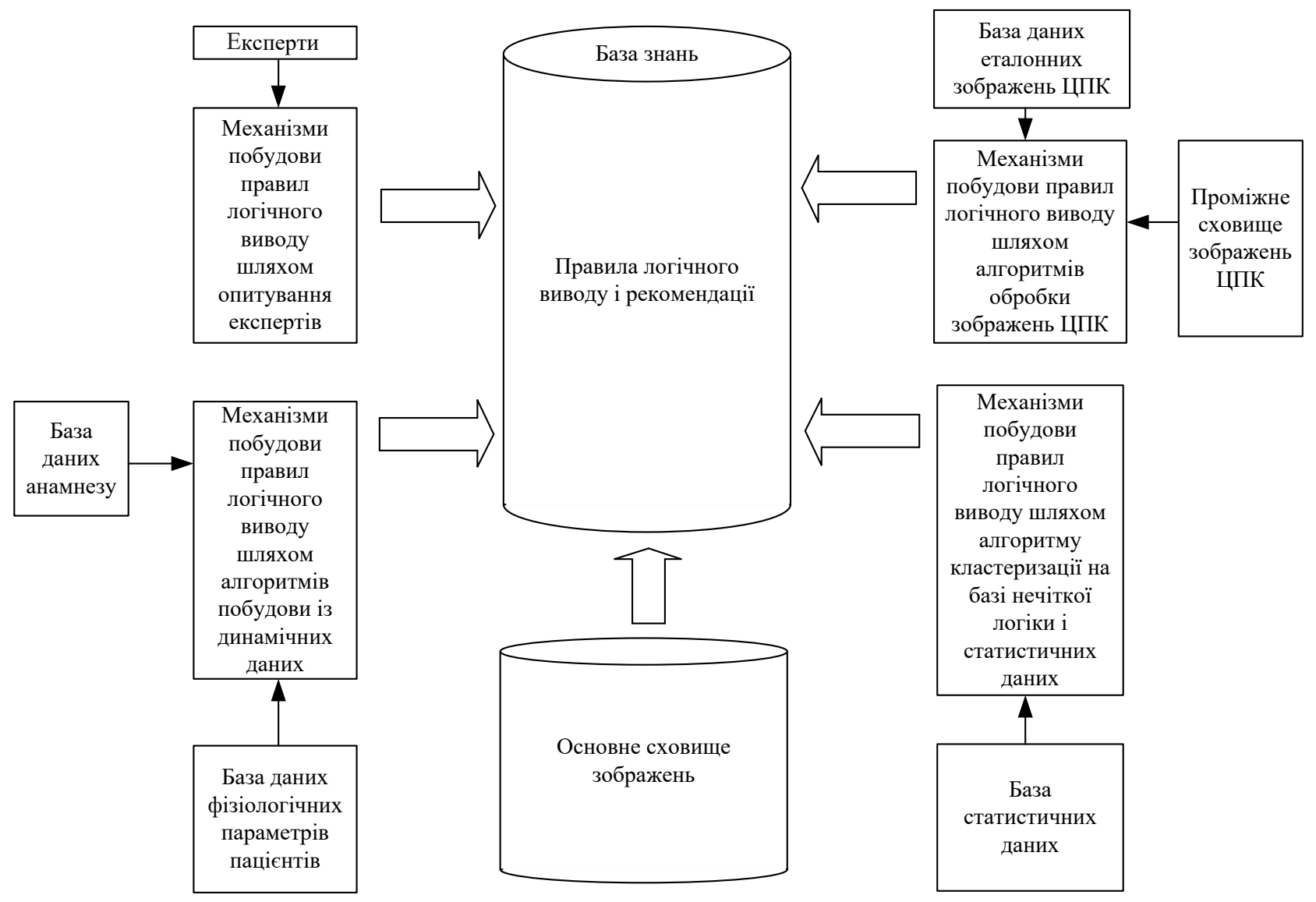

Рис. 2. Етапи побудови бази знань ПППР.

\section{Висновки}

1. Ідентифікація ЦПК залишається складною задачею, яка практично недоступна клінічним лікарям через відсутність відповідних медичних протоколів і технологічних стандартів виявлення ЦПК.

2. Узагальнені недоліки методів засобів і систем можна класифікувати за високою вартістю, складністю і трудомісткістю дослідження проце- су виявлення ЦОК у крові пацієнта; довготривалістю і низькою достовірністю отриманих результатів.

3. Одним із шляхів вирішення проблеми може стати застосування запропонованої авторами інформаційної системи для отримання та оброблення мікроскопічних зображень ЦПК для ранньої діагностики онкологічних захворювань.

\section{ЛІТЕРАТУРА}

1. Определение содержания ЦПК в периферической крови у больных с первично-генерализованным раком молочной железы на этапах лечения [Электронный ресурс] - Режим доступа: http://www. science-education.ru/ru/article/view?id=22788

2. A rare-cell detector for cancer / R. Krivacic, A. Ladanyi, D. Curing [et al.] // Proceedings of the National Academy of Sciences of the United States of America. - 2004. Vol. 101, No. 29. - P. 10501-10504.

3. Detection of circulating tumour cells in peripheral blood with an automated scanning fluorescence microscope / T. Ntouroupi, S. Ashraf, S. McGregor [et al.] // British Journal of Cancer. - 2008. - Vol. 99, No. 5. - P. 789-795.

4. Monitoring circulating epithelial tumour cells (CETC) to gauge therapy: in patients with disease progression after trastuzumab persisting CETC can be eliminated by com- bined lapatinib treatment / O. Camara, C. Jorke, U. Hammer [et al.] // Journal of Cancer Research and Clinical Oncology.2009. - Vol. 135, No. 4. - P. 643-647.

5. Comparison of assay methods for detection of circulating tumor cells in metastatic breast cancer: AdnaGen AdnaTest BreastCancer Select/Detect ${ }^{\mathrm{TM}}$ versus Yeridex CellSearch $^{\text {TM }}$ system / E. Andreopovlou, L.-Y. Yang, K. Rangel [et al.] // Int. Journal of Cancer. - 2012. - Vol. 130, No. 7. P. 1590-1597.

6. A sample preparation and analysis system for identification of circulating tumor cells / M. Kagan, D. Howard, T. Bendele [et al.] // Journal of Clinical Ligand Assay. 2002. - Vol. 25, No. 1. - P. 104-110.

7. Reliable and sensitive analysis of occult bone marrow metastases using automated cellular imaging / K. Bauer, J. de la Tom-Bueno, I. Diel [et al.] // Clinical Cancer Re- 
Огляди літератури, оригінальні дослідження, погляд на проблему

search: An Official Journal of the American Association for Cancer Research. - 2000. - Vol. 6, No. 9. - P. 3552-3559.

8. Detection and analysis of cancer cells in blood and bone marrow using a rare event imaging system / S. Kraeft, R. Sutherland, L. Gravelin [et al.] // Clinical Cancer Research: An Official Journal of the American Association for Cancer Research. - 2000. - Vol. 6, No. 2. - P. 434-442.

9. Negin B. Circulating tumor cells in colorectal cancer: past, present, and future challenges / B. Negin, S. Cohen // Current Treatment Options in Oncology. - 2010. Vol. 11, No. 1-2. - P. 1-13.

10. Circulating tumour cell detection: a direct comparison between the CellSearch System, the AdnaTest and CK-19/mammaglobin RT-PCR in patients with metastatic breast cancer / I. Van der Auwera, D. Peeters, I. Benoy [et al.] // British Journal of Cancer. - 2010. - Vol. 102, No. 2. P. 276-284.

11. Enrichment with anti-cytokeratin alone or combined with anti-EpCAM antibodies significantly increases the sensitivity for circulating tumor cell detection in metastatic breast cancer patients / G. Deng, M. Herrler, D. Burgess [et al.] // Breast Cancer Res. - 2008. - Vol. 10, No. 4. - P. 69.

12. Microdevice for the isolation and enumeration of cancer cells from blood / S. Tan, L. Yobas, G. Lee [et al.] // Biomedical Microdevices. - 2009. - Vol. 11, No. 4. P. 883-892.

13. Isolation of rare circulating tumour cells in cancer patients by microchip technology / S. Nagrath, L. Sequist, S. Maheswaran [et al.] // Nature. - 2007. - Vol. 450, No. 7173. - P. 1235-1239.

14. Isolation by size of epithelial tumor cells: A new method for the immunomorphological and molecular characterization of circulatingtumor cells / G. Vona, A. Sabile, M. Louha [et al.] // The American Journal of Pathology. - 2000. - Vol. 156, No. 1. - P. 57-63.

15. Detection of circulating tumor cells in blood using an optimized density gradient centrifugation / R. Gertler,

\section{REFERENCES}

1. Opredelenie soderzhaniya TsPK v perifericheskoy krovi u bolnykh s pervichno-generalizovannym rakom molochnoy zhelezy na etapakh lecheniya [Determination of the content of CPC in peripheral blood in patients with primary generalized breast cancer at the stages of treatment]. [Elektronnyi resurs] - Retrieved from: http://www.scienceeducation.ru/ru/article/view?id=22788 [in Russian].

2. Krivacic, R., Ladanyi, A., Curing, D., Hsieh, H., Kuhn, P., Bergsrud, D. et al. (2004). A rare-cell detector for cancer. Proceedings of the National Academy of Sciences of the United States of America, 101 (29), 10501-10504.

3. Ntouroupi, T., Ashraf, S., McGregor, S., Turney, B., Seppo, A., Kim, Y. et al. (2008). Detection of circulating tumor cells in peripheral blood with an automated scanning fluorescence microscope. British Journal of Cancer, 99 (5), 789-795.

4. Camara, O., Jorke, C., Hammer, U., Egbe, A., Rabenstein, C., Runnebaum, I. et al. (2009). Monitoring circulating epithelial tumor cells (CETC) to gauge therapy: in patients with disease progression after trastuzumab persis-
R. Rosenberg, K. Fuehrer [et al.] // Recent Results in Cancer Research. Fortschntte der Krebsforschung. Progres clans les recherches sur le cancer. - 2003 - Vol. 162. P. 149-155.

16. Бурденюк І. І. Інформаційна технологія для підтримки прийняття рішень при аналізі біомедичних даних : автореф. дис. на здобуття наукового ступеня канд. технічних наук. Спеціальність 05.13.06 - інформаційні технології. Вінниця, $2010-15$ с.

17. Бурденюк І. І. Оптико-електронні методи контролю біотехнічних зображень / В. П. Кожем' яко, Н. П. Ганиш, І. І. Бурденюк // Оптико-електронні інформаційні енергетичні технології. - 2007. - № 2 (14). - С. 198-208.

18. Бурденюк І. І. Оптико-електронні інформаційні технології контролю реологічних властивостей крові / В. П. Кожем' яко, С. В. Павлов, І. І. Бурденюк // Інформаційні технології комп' ютерної інженерії. - 2007. - № 1. C. $75-80$.

19. Кожем'яко В. П. Оптико-електронні методи і засоби для обробки та аналізу біомедичних зображень [монографія] / В. П. Кожем'яко, С. В. Павлов, К. І. Станчук. - Вінниця : УНІВЕРСУМ, 2006-203 с.

20. Павлов С. В. Разработка и исследования оптоэлектронной информационно-идентифицирующей системы исследования биомедицинской информации : дисс. на соискание ученой степени канд. техн. наук // Павлов Сергей Владимирович. - Винница, 1995. - 114 с.

21. Гончарова А. Б. Система поддержки принятия решений в медицине для диагностики заболеваний / А. Б. Гончарова, Е. И. Сергеева // [Электронный ресурс]. Режим доступа: https://sibac.info/journal/innovation/62/ 68210

22. Крошилин А. В. Проектирование систем поддержки принятия решений в медицине для диагностики заболеваний / А. В. Крошилин, С. В. Крошилина, А. Н. Пилькин // Интеллектуальные системы. - 2010. №4 (26). - С. 82-94.

ting CETC can be eliminated by combined lapatinib treatment. Journal of Cancer Research and Clinical Oncology, 135 (4), 643-647.

5. Andreopovlou, E., Yang, L.-Y., Rangel, K., Reuben, J., Hsu, L., Krishnamurthy, S. et al. (2012). Comparison of assay methods for detection of circulating tumor cells in metastatic breast cancer: Adna Gen Adna Test Breast Cancer Select/Detect ${ }^{\mathrm{TM}}$ versus Yeridex CellSearch ${ }^{\mathrm{TM}}$ system. Int. Journal of Cancer, 130 (7), 1590-1597.

6. Kagan, M., Howard, D., Bendele, T., Mayes, J., Silvia, J., Repollet, M. et al. (2002). A sample preparation and analysis system for identification of circulating tumor cells. Journal of Clinical Ligand Assay, 25 (1), 104-110.

7. Bauer, K., de la Tom-Bueno, J., Diel, I., Hawes, D., Decker, W., Priddy, C. et al. (2000). Reliable and sensitive analysis of occult bone marrow metastases using automated cellular imaging. Clinical Cancer Research: An Official Journal of the American Association for Cancer Research, 6 (9), 3552-3559.

8. Kraeft, S., Sutherland, R., Gravelin, L., Hu, G., Ferland, L., Richardson, P. et al. (2000). Detection and analysis 
Огляди літератури, оригінальні дослідження, погляд на проблему

of cancer cells in blood and bone marrow using a rare event imaging system. Clinical Cancer Research: An Official Journal of the American Association for Cancer Research, 6 (2), 434-442.

9. Negin, B., \& Cohen, S. (2010). Circulating tumor cells in colorectal cancer: past, present, and future challenges. Current Treatment Options in Oncology, 11 (1-2), 1-13.

10. Van der Auwera, I., Peeters, D., Benoy, I., Elst, H., Van Laere, S., Prove, A. et al. (2010). Circulating tumour cell detection: a direct comparison between the CellSearch System, the AdnaTest and CK-19/mammaglobin RT-PCR in patients with metastatic breast cancer. British Journal of Cancer, 102 (2), 276-284.

11. Deng, G., Herrler, M., Burgess, D., Manna, E., Krag, D., Burke, J. (2008). Enrichment with anti-cytokeratin alone or combined with anti-EpCAM antibodies significantly increases the sensitivity for circulating tumor cell detection in metastatic breast cancer patients. Breast Cancer Res., 10 (4), 69.

12. Tan, S., Yobas, L., Lee, G., Ong, C., \& Lim, C. (2009). Microdevice for the isolation and enumeration of cancer cells from blood. Biomedical Microdevices, 11 (4), 883-892.

13. Nagrath, S., Sequist, L., Maheswaran, S., Bell, D., Irimia, D., Ulkus, L. et al. (2007). Isolation of rare circulating tumour cells in cancer patients by microchip technology. Nature, 450 (7173), 1235-1239.

14. Vona, G., Sabile, A., Louha, M., Sitruk, V., Romana, S., Schutze, K. et al. (2000). Isolation by size of epithelial tumor cells: A new method for the immunomorphological and molecular characterization of circulatingtumor cells. The American Journal of Pathology, 156 (1), 57-63.

15. Gertler, R., Rosenberg, R., Fuehrer, K., Dahm, M., Nekarda, H., Siewert, J. (2003). Detection of circulating tumor cells in blood using an optimized density gradient centrifugation. Recent Results in Cancer Research. Fortschntte der Krebsforschung. Progres clans les recherches sur le cancer, 162, 149-155.

16. Burdeniuk, I.I. (2010). Informatsiina tekhnolohiia dlia pidtrymky pryiniattia rishen pry analizi biomedych- nykh danykh [Information technology to support decisionmaking in the analysis of biomedical data]. Extended $a b$ stract of Candidate's thesis: Vinnytsia [in Ukrainian].

17. Kozhemiako, V.P., Hanish, N.P., Burdeniuk, I.I. (2007). Optyko-elektronni metody kontroliu biotehnichnykh zobrazhen [Optoelectronic methods for the control of biotechnical images]. Optiko-elektronni informatsiini enerhetychni tekhnolohii-Optoelectronic Information Energy Technologies, 2 (14), 198-208 [in Ukrainian].

18. Burdeniuk, I.I., Kozhemiako, V.P., \& Pavlov, S.V. (2007). Optyko-elektronni informatsiini tekhnolohii kontroliu reolohichnykh vlastyvostei krovi [Optoelectronic information technology control of reologic authorities in the blood]. Informatsiini tekhnolohii kompiuternoi inzhenerii - Information Technology of Computer Engineering, 1, 7580 [in Ukrainian].

19. Kozhemiako, V.P., Pavlov, S.V., \& Stanchuk, K.I. (2006). Optyko-elektronni metody i zasoby dlia obrobky ta analizu biomedychnykh zobrazhen [Optoelectronic methods and gaps for the analysis of the analysis of biomedical imaes]. Vinnytsia: UNIVERSUM [in Ukrainian].

20. Pavlov, S.V. (1995). Razrabotka i issledovaniya optoelektronnoy informatsionno-identifitsiruyushchey sistemy issledovaniya biomeditsinskoy informatsii [Development and research of optoelectronic information-identifying system of research of biomedical information]. Extended abstract of Candidate's thesis. Vinnytsia [in Russian].

21. Goncharova, A.B., Sergeeva, E.I. Sistema podderzhki prinyatiya resheniy $v$ meditsine dlya diagnostiki zabolevaniy [System of support of decision-making in medicine for diagnostics of diseases]. Retrieved from: https://sibac.info/ journal/innovation/62/68210 [in Russian].

22. Kroshilin, A.V., Kroshilina, S.V., \& Pilkin, A.N. (2010). Proektirovanie sistem podderzhki prinyatiya resheniy $\mathrm{v}$ meditsine dlya diagnostiki zabolevaniy [Designing of decision support systems in medicine for the diagnosis of diseases]. Intellektualnye sistemy - Intelligent Systems, 4 (26), 82-94 [in Russian].

\title{
ИНФОРМАЦИОННАЯ СИСТЕМА ДЛЯ ПОЛУЧЕНИЯ И ОБРАБОТКИ МИКРОСКОПИЧЕСКИХ ИЗОБРАЖЕНИЙ ЦИРКУЛИРУЮЩИХ ОПУХОЛЕВЫХ КЛЕТОК
}

\author{
๑С. М. Злепко1, Т. А. Чернышева ${ }^{3}$, С. В. Тимчик' ${ }^{1}$ В. Е. Кривоносов ${ }^{2}$, А. С. Злепко 4 \\ Винницкий национальный технический университет 1 \\ Приазовский государственный технический университет² \\ Медицинский центр авиационного университета, Киев ${ }^{3}$ \\ Винницкий национальный медицинский университет имени Н. И. Пирогова ${ }^{4}$
}

\begin{abstract}
РЕЗЮМЕ. В статье приведена структура и реализация информационной системы для получения и обработки микроскопических изображений ЦОК. Определено, что идентификация ЦОК является сложной задачей, которая практически недоступна клиническим врачам вследствие отсутствия соответствующих медицинских протоколов и технологических стандартов выявления ЦОК. Приведены методы выделения ЦОК, а именно: технологии разделения по морфологическим признакам, метод разделения по градиенту плотности с использованием центрифугирования и последующего выделения технологии OncoQuick ЦОК, иммуномагнитные методы, в которых опухолевые клетки взаимодействуют с антителами против маркеров ЦОК с конъюгированными магнитными частицами, после чего раковые клетки можно получить с помощью магнитного поля, и их недостатки. Разработанная информационная система для получения и анализа микроскопических изображений ЦОК состоит
\end{abstract}


Огляди літератури, оригінальні дослідження, погляд на проблему

из 4 подсистем: фильтрации венозной крови; получения и предварительной обработки изображений цОК; формирования изображений ЦОК и «интеллектуальной» обработки изображений ЦОК, вместе с подсистемой фильтрации венозной крови пациента представляет собой базовый структурный элемент информационной технологиидля определенияциркулирующих опухолевыхклетокв кровичеловека. Особенностью разработанной системы является введение в ее структуру подсистемы «интеллектуальной» обработки изображений цОК, выполняет функции подсистемы поддержания принятия решений и обеспечивает практически $100 \%$ соответствие поставленного диагноза реальной ситуации, исключив неоднозначность в его интерпретации. Найдено решение проблемы, а именно применение предложенной авторами информационной системы для получения и обработки микроскопических изображений ЦОК для ранней диагностики онкологических заболеваний.

КЛючЕВЫЕ СлОВА: циркулирующие опухолевые клетки; выявление опухолевых клеток; компьютерный анализ.

\title{
INFORMATION SYSTEM FOR RECEIVING AND PROCESSING MICROSCOPIC IMAGES OF CIRCULATING TUMOR CELLS
}

\author{
S. M. Zlepko1, T. A. Chernyshova ${ }^{3}$, S. V. Timchik', V. Ye. Krivonosov'², O. S. Zlepko ${ }^{4}$ \\ Vinnytsia National Technical University ${ }^{1}$ \\ Pryazov State Technical University ${ }^{2}$ \\ Medical Center of Aviation University, Kyiv ${ }^{3}$ \\ M. Pyrohov Vinnytsia National Medical University ${ }^{4}$
}

\begin{abstract}
SUMMARY. The article presents the structure and implementation of an information system for obtaining and processing microscopic images of the circulating tumor cells (CTC). It is determined that identification of CTC is a complex task, which is practically inaccessible to clinical doctors due to the absence of relevant medical protocols and technological standards for the detection of CTC. The methods of isolation of the CTC are given, and the seven: the technology of separation by morphological features, the method of dividing by density gradient, using centrifugation and subsequent allocation by the OncoQuick technology of the CTC, immune-magnetic methods in which tumor cells interact with antibodies against the markers of CTC with conjugated magnetic particles, after which the cancer cells can be obtained by means of a magnetic field, and their disadvantages. The information system for obtaining and analyzing microscopic images of the CTC, which consists of 4 subsystems: venous blood filtration is developed. Receiving and preprocessing images of the CTC; the formation of images of the CTC and the «intellectual» image processing of the CTC, which, together with the patient's venous blood filtration subsystem, is the basic structural element of information technology for the determination of circulating tumor cells in human blood. The peculiarity of the developed system is the introduction into its structure of the subsystem of «intellectual» image processing of the CTC, which serves as a subsystem of maintaining decision-making and provides almost $100 \%$ conformity of the diagnosis to the actual situation, eliminating ambiguity in its interpretation. The problem solving was found, namely, the application of the information system proposed by the authors for the receipt and processing of microscopic images of the CTC for early diagnosis of oncology diseases.
\end{abstract}

KEY WORDS: circulating tumor cells; detecting tumor cells; computer analysis. 